\title{
An Opportunity to Challenge the "Color Line": Gender, Race, Ethnicity, and Women's Labor Activism in Late Nineteenth-Century Cedar Rapids, Iowa
}

\author{
BRIE SWENSON ARNOLD
}

LATE IN THE SUMMER OF 1897, 20-year-old Emma Oliphant noticed a help wanted ad in the Cedar Rapids Evening Gazette: "WANTED: Overall and duck coat makers. Apply at factory. Liddle \& Carter." The ad appeared in the Gazette on numerous occasions throughout August as Liddle \& Carter attempted to fill dozens of sewing positions in its garment factory in downtown Cedar Rapids. ${ }^{1}$ The ad was not unusual-Liddle \& Carter and

The author wishes to thank Cinnamon Moore, Mia Phifer, and Emily Weber for their research assistance and Marvin Bergman and the Annals of Iowa's anonymous reviewers for their helpful comments on earlier versions of this article. Research for this article was supported by Ella Pochobradsky Endowment Grants for Faculty-Student Research at Coe College.

1. Bureau of the Census, U.S. Federal Census (1900) (this and all census information throughout accessed via ancestry.com); "Wanted-Overall \& Duck Coat Makers," Cedar Rapids Evening Gazette (hereafter cited as Gazette), 8/6/1897, 8/9/1897, 8/14/1897, 8/16/1897, 8/17/1897, 8/20/1897, and 8/25/1897. Liddle \& Carter produced men's shirts, coats, and overalls. It was established in Cedar Rapids in the 1870s and employed as many as 100 women and men by the 1890s. "Wholesale Furnishing Goods \& Manufacturing Business," Linn County Timelines: The Newsletter of the Linn County Historical Society (October 1997), in "Manufacturers" file, Linn County Historical Society Library and Archives, Cedar Rapids; "New Factory: Liddle \& Carter Make Plans for the Future," Gazette, 5/6/1897.

THE ANNALS OF IOWA 74 (Spring 2015). (C) The State Historical Society of Iowa, 2015. 
many factories in Cedar Rapids routinely advertised for female operatives in the 1890s - but something about this ad stuck in Emma Oliphant's mind. Maybe it was because garment factory positions were among the best-paying jobs for women in the city. Maybe Oliphant had heard about this kind of work from the many women living in her neighborhood who worked at Liddle \& Carter. Maybe, since the factory was looking to hire many new operatives, Oliphant was excited about the prospect of landing a position for herself and several of her good friends. Or maybe this was just the opportunity she had been waiting for to challenge the "color line" in women's factory work in Cedar Rapids.

Help wanted ads like those placed by Liddle \& Carter never said so, but factory jobs for women in late nineteenth-century Cedar Rapids were understood to be for white women only. Emma Oliphant and the six other African American women who decided to apply at Liddle \& Carter in August 1897 surely knew that. Still, they resolved to collectively confront the racial discrimination that existed in women's work in Cedar Rapids. With Oliphant leading the effort, the seven women easily secured sewing jobs through written correspondence with Liddle \& Carter manager Chester E. Clark. ${ }^{2}$

Yet when Oliphant, Mattie Wade, Mary Bowlin, Flora Bouey, Jessie Martin, Pearl Wood, and Mattie Price arrived at the factory, "ready to begin their labors" on the morning of September 2, "there was trouble." "The white women and girls" already working at Liddle \& Carter "rose up unanimously and threatened to leave the employment of the company in case the colored girls were allowed to work." For more than an hour that Thursday morning, words were exchanged between the existing female employees, manager Clark, and at least one of the new hiresEmma Oliphant. At some point during the confrontation, Clark "became very angry and tried to thrust them [the seven black women] from the building, and in doing so he shoved Miss Emma Oliphant against the door, almost breaking her arm." Clark told the seven new hires that "the whites would leave were

2. “Threatened to Strike," Gazette, 9/2/1897. On Clark's identity, see Cedar Rapids City Directories (1895-1900), Digital Archives of the Marion Public Library, http://mpl.newspaperarchive.com; Iowa State Census (1895); Federal Census (1900). 
the colored girls allowed to sit down to a machine." Because he claimed he couldn't afford to "lose seventy skilled employees," Clark said he was "compelled to draw the color line." But the matter was not resolved in that moment. Emma Oliphant and the six other "girls would not be dealt with in such a way." They said they would continue to "report for work" at Liddle \& Carter "until they learn definitely whether they will be allowed to work." With the hiring of the black women still in question, the white women workers went ahead with their strike. ${ }^{3}$

The story of the confrontation at Liddle \& Carter offers compelling insights into the complexities of women's work, labor activism, and consciousness in late nineteenth-century America, when the "color line" was being redrawn and challenged in many places across the United States. In Cedar Rapids in the late 1890s, diverse working women launched labor protests in efforts to improve their working conditions and to assert collective, if racially specific, senses of themselves as both laborers and ladies. The actions and collective identities of the black and white women involved in the events surrounding the conflict at Liddle \& Carter were shaped not only by gender and class but by race, ethnicity, and the social and economic dynamics of the diverse community that was turn-of-the-century Cedar Rapids. This case offers a glimpse into the nuances of race and ethnicity in women's work and labor activism, northern racial discrimination and resistance to it on the part of black women, and what historian Eric Arnesen refers to as "white labor's role in maintaining and even creating Jim Crow." 4

From the 1860s onward, African American women in Iowa and across the nation became particularly influential advocates for black rights and equality. ${ }^{5}$ By emphasizing their status as "ladies,"

3. "Threatened to Strike," Gazette, 9/2/1897; "Cedar Rapids Budgetarian" (hereafter cited as "CRB"), Iowa State Bystander (hereafter cited as Bystander), 9/10/1897; "News in Iowa," Marion Sentinel, 9/30/1897; "Color Line," Gazette, 9/4/1897.

4. Eric Arnesen, "Up from Exclusion: Black and White Workers, Race, and the State of Labor History," Reviews in American History 26 (1998), 149.

5. Leslie Schwalm, Emancipation's Diaspora: Race and Reconstruction in the Upper Midwest (Chapel Hill, NC, 2009); Barbara Young Welke, Recasting American Liberty: Gender, Race, Law, and the Railroad Revolution, 1865-1920 (New York, 2001); Jacqueline Jones, Labor of Love, Labor of Sorrow: Black Women, Work, and the Family from Slavery to the Present (New York, 1985); Tera Hunter, To 'Joy My Freedom: 
black women asserted that gender entitled them to particular job opportunities, social prerogatives, and legal rights often denied them because of race. Such claims, the women hoped, might open the door to better opportunities, treatment, and rights for themselves and for African Americans more broadly. The activism of Emma Oliphant and the six other black women who attempted to desegregate women's work at Liddle \& Carter offers a compelling example of this. With their action, Oliphant and the other women deliberately challenged racist practices and assumptions and asserted their right to be treated fairly as laborers and ladies. At the same time, the white women already working at Liddle \& Carter launched protests and asserted their own sense of themselves as ladies and laborers that was rooted in their racial and ethnic identity. During the latter phases of the nineteenth century - amid urbanization, industrialization, labor unrest, major migrations to and within the United States, enduring and emerging patterns of racial discrimination, and shifts in women's work, "urban black women entered this maelstrom as labor activists or determined opponents to Jim Crow." 6

ALL OF THOSE CURRENTS swirled through and shaped Cedar Rapids, yet scholars have done little to document the city's rich working-class, women's, and African American history. In many ways, Cedar Rapids was a prototypical American city during the age of immigration, industrialization, and urbanization. In the decades following the Civil War, its population expanded dramatically from about 1,000 residents in 1860 to 10,000 by 1880 and nearly 41,000 by $1915 .^{7}$ Such cities, observes historian Sharon Wood, offer a far more typical picture of the experiences of ordinary Americans in this period than those of more oft-studied cities like New York City and Chicago. By 1880, Wood explains,

Southern Black Women's Lives and Labors after the Civil War (Cambridge, MA, 1998); Deborah Gray White, Too Heavy a Load: Black Women in Defense of Themselves, 1894-1994 (New York, 1999).

6. Jones, Labor of Love, Labor of Sorrow, 147.

7. "Urban Population," in Census of Iowa for the Year 1915 (Des Moines, 1915), 579; State Data Center of Iowa, "Total Population for Iowa's Incorporated Places: 1850-2000," http://data.iowadatacenter.org/datatables/PlacesAll/plpopulation18502000.pdf; Harold F. Ewoldt, “C.R. History,” Gazette, 8/13/1989. 
"more Americans lived in urban places of twelve thousand to seventy-five thousand than in cities with populations of half a million or more." 8

Between 1870 and 1920, diverse peoples were drawn to Cedar Rapids by the prospect of employment and economic opportunities. The city was home to some of the nation's - indeed, the world's - largest cereal and meatpacking plants, including American Cereal Company (the forerunner to Quaker Oats) and Sinclair \& Company (later Wilson and Company). ${ }^{9}$ Smaller factories, banks, retail shops, department stores, hospitals, schools, and offices also emerged throughout the city.

The rapid growth of industry brought an influx of people from a wide variety of places, making Cedar Rapids more ethnically and racially diverse than many other locales in Iowa and the Midwest. Around the turn of the twentieth century, immigrants and the children of newly arrived immigrants made up half the population of Cedar Rapids. ${ }^{10}$ Immigrants from many backgrounds, including Irish, German, Canadian, Swedish, Swiss, Syrian, and Lebanese, resided in Cedar Rapids, with Bohemians constituting the largest ethnic group. ${ }^{11}$ In fact, the vast majority of the white women working at Liddle \& Carter in the late 1890s were Bohemian. Some of these women, like Rosie Pelikan, Mary Kratochvil, Augusta Pizinger, Pearl and Mary Langer, and Amelia and Mary Popelka, had recently emigrated from the historical region of Bohemia; others, like Frances Cerny, Kate Charipar, Stella Ripka, Julia and Mary Burianek, Emma and Mary Kozak, and Fanny and Annie Zastera, were the Iowa-born daughters of Bohemian immigrants. ${ }^{12}$

8. Sharon E. Wood, The Freedom of the Streets: Work, Citizenship, and Sexuality in a Gilded Age City (Chapel Hill, NC, 2005), 9.

9. “Our Greatest Home Industry," Gazette, 1/1/1901; “3,000 Barrel Mill,” Gazette, 10/18/1899; "History of Sinclair and Co.," Brucemore Historic Site, www.brucemore.org/history/people/sinclair/.

10. Census of Iowa for the Year 1915, 233-36.

11. Bohemians constituted perhaps a quarter of the city's population. See Pam Stek, "The 1898 American Cereal Company Strike in Cedar Rapids: Gender, Ethnicity, and Labor in Late Nineteenth-Century Iowa," Annals of Iowa 74 (2015), 142-76 (immediately following this article).

12. Cedar Rapids City Directory (1898); Federal Census (1880, 1900, and 1910). 
Native-born Americans originally from eastern and southern states also migrated to Cedar Rapids in significant numbers during the late nineteenth and early twentieth centuries. While many of the city's native-born whites were originally from places like New York, Massachusetts, Pennsylvania, Michigan, and Illinois, most of its African American residents had been born in the South. The end of slavery triggered a major northward migration of African Americans, with the Midwest being the region to which the majority of post-Civil War black migrants relocated. ${ }^{13}$ Given that midwestern states - including Iowa-had restricted or barred black settlement in the antebellum era, the migration of the postwar era was a significant development. ${ }^{14}$ According to historian Leslie Schwalm, more than 6,000 black migrants streamed into the upper midwestern states of Iowa, Minnesota, and Wisconsin in the period from 1860 to 1870 alone. The vast majority settled in Iowa. Just over a thousand African Americans lived in the state in 1860; the federal census of 1870 reported 5,762 black residents. By the close of World War I, there were more than 19,000 black Iowans. Clearly, as historian Jack Blocker explains, the flood of the post-World War I Great Migration so well known to scholars and most Americans was "preceded by a half century trickle," a slower but steady migration of African American from the South to the Midwest. ${ }^{15}$

That trend was clearly visible in Cedar Rapids. No African Americans were documented as living in Cedar Rapids prior to 1865 , but by 1870 there were at least 50 - and probably closer to

13. Schwalm, Emancipation's Diaspora; Nell Irvin Painter, Exodusters: Black Migration to Kansas after Reconstruction (New York, 1977); Jack Blocker, A Little More Freedom: African Americans Enter the Urban Midwest, 1860-1930 (Columbus, OH, 2008); William C. Cohen, At Freedom's Edge: Black Mobility and the Southern White Quest for Racial Control, 1861-1915 (Baton Rouge, LA, 1991); Michael P. Johnson, "Out of Egypt: The Migration of Former Slaves to the Midwest during the 1860s in Comparative Perspective," in Crossing Boundaries: Comparative History of Black People in Diaspora (Bloomington, IN, 1999).

14. Laws of Iowa, 1838-1839, 1840, 1850-1851; Leola Nelson Bergmann, The Negro in Iowa (1948; reprint, Iowa City, 1969), 8-15; V. Jacque Voegeli, Free but Not Equal: The Midwest and the Negro during the Civil War (Chicago, 1967).

15. Schwalm, Emancipation's Diaspora, 45; Bergmann, The Negro in Iowa, 34; Blocker, A Little More Freedom, 219. See also James L. Hill, "Migration of Blacks to Iowa," Journal of Negro History 66 (1981-1982), 289-303. 
100-black residents of the city. ${ }^{16}$ The black population grew steadily, with about 200 black residents by 1880, 300 by 1900, and close to 1,000 by $1915 .{ }^{17}$

Emma Oliphant's parents were among these early black settlers in Cedar Rapids. Thomas and Anna Oliphant had in all likelihood experienced slavery firsthand, as Thomas was born in Tennessee in the late 1830s and Anna in South Carolina in the 1850s. 18 It is unclear when Anna was liberated from bondage, but by 1864 at least Thomas Oliphant was no longer a slave and was living in the North. At that time, he enlisted in the 43rd U.S. Colored Infantry, which saw extensive action in the eastern theater during the last grueling phases of the Civil War. ${ }^{19}$ At some point after he was mustered out of the army (at the rank of corporal), Oliphant made his way to Iowa. Thomas and Anna met either just before or just after arriving in Iowa; by 1870, they were married and living in the booming railroad town of Montana, Iowa, near the presentday city of Boone, just north of Ames and Des Moines. ${ }^{20}$ There,

16. Bergmann, The Negro in Iowa, 34; The History of Linn County (Chicago, 1878), as cited in Eric A. Smith, Oak Hill: A Portrait of Black Life in Cedar Rapids, Iowa (Los Angeles, 2006), 41; Willis Goudy, "Selected Demographics: Iowa's AfricanAmerican Residents, 1840-2000," in Outside In: African-American History in Iowa, 1838-2000, ed. Bill Silag (Des Moines, 2001), 40-41; Census of Iowa for the Year 1895 (Des Moines, 1896). My own tabulations from city directories, cemetery records, newspaper articles, and the federal census found at least 36 African Americans living in just Cedar Rapids (much less all of Linn County) in 1870. On census under-enumeration of African Americans, see Dernoral Davis, "Toward a Socio-Historical and Demographic Portrait of Twentieth-Century African-Americans," in Black Exodus: The Great Migration from the American South, ed. Alferdteen Harrison (Jackson, MS, 1991), 2-3.

17. “CRB," Bystander, 3/3/1899; "A Visit to the White City," Bystander, 4/2/ 1899; Goudy, "Selected Demographics," 41; Census of Iowa for the Year 1895, 127; Gabriel Victor Cools, "The Negro in Typical Communities of Iowa" (M.A. thesis, University of Iowa, 1918); Bergmann, The Negro in Iowa, 34.

18. Federal Census (1870). Gravestones in Oak Hill Cemetery, Cedar Rapids, list their birth years as 1838 and 1852.

19. National Park Service (NPS) database of Civil War soldiers, http:/ /www .nps.gov/civilwar/search-soldiers.htm; NPS, "43rd Regiment, United States Colored Infantry," http://www.nps.gov/civilwar/search-battle-units-detail .htm?battleUnitCode=UUS0043RI00C; National African American Civil War Memorial list of soldiers, http://www.nps.gov/civilwar/search-soldiers-detail .htm?soldier_id=ff663dc0-dc7a-df11-bf36-b8ac6f5d926a.

20. Federal Census (1870); Boone County Historical Society, "County History," http://www.boonecounty.iowa.gov/index.aspx?page=282. 
they found jobs in a hotel, Thomas as a groom and Anna as a domestic servant. After that stint in Montana - where they were among less than a dozen black folk living in all of Boone County - Thomas and Anna decided to relocate to the larger city of Cedar Rapids. ${ }^{21}$ By 1880, Thomas and Anna Oliphant were firmly established in Cedar Rapids, along with the four children they had welcomed since moving to Iowa: John, George, Emma, and Hellen. 22

In the last quarter of the nineteenth century, Cedar Rapids looked like - and in many ways was - a good choice for black migrants like the Oliphants. In the late nineteenth century, African American newspapers often extolled the virtues of the great state of Iowa. The Weekly Louisianan, for example, explained that it was a place that offered "employment ... both for men and women" where "the foundation of ... riches and prosperity" might be laid for black men and women coming of age in the wake of slavery, the Civil War, and Reconstruction. ${ }^{23}$

Soon after arriving in Cedar Rapids, Thomas Oliphant found a job as a blacksmith while Anna "kept house" and looked after their growing family. The family settled in the Oak Hill neighborhood, a racially and ethnically diverse working-class neighborhood on the southeast side of Cedar Rapids. By the mid-1890s, the Oliphants were established in the house at 520 Tenth Avenue that they would live in for decades. ${ }^{24}$ Just a few years after moving in, they managed to purchase this home free and clear of any

21. Federal Census (1870); “African American Residents of Iowa's Counties, 1840-1990," Outside In, 40-41. Such movement from the South to rural and then urban areas in the Midwest was a typical migration pattern for many African Americans in the late nineteenth century. See Blocker, A Little More Freedom.

22. Federal Census (1880, 1900); Iowa State Census (1885); Oak Hill Cemetery gravestones. Additional children, including Florence, Grace, James, William, and Bessie, arrived after the move to Cedar Rapids. The 1900 census indicates that Anna had ten children, with six still living in 1900. Emma was listed in some records as "Mary Emma" or "Mary E" but always went by "Emma."

23. "Colonization Schemes," Weekly (New Orleans) Louisianan, 10/6/1877. See also "Our Colored Citizens," Huntsville (AL) Gazette, 3/17/1888; and Schwalm, Emancipation's Diaspora, 137.

24. Cedar Rapids City Directories (1890-1910); Federal Census (1900, 1910). On Oak Hill, see Cools, "The Negro in Typical Communities of Iowa," 95-96; Smith, Oak Hill; and "African American Footprints of Cedar Rapids, Iowa," http:/ / africanamericanfootprints.blogspot.com. 
mortgage - an accomplishment shared by many black migrants to the Midwest. 25

Like the Oliphants, Bohemian immigrants Frank and Anna Popelka also saw Cedar Rapids as a promising place in which to raise a growing family. They, too, migrated to Cedar Rapids in the 1880s - in their case from Bohemia. The Popelkas also settled in Oak Hill and eventually purchased their home at 921 South Ninth Street, just a few blocks from the Oliphants. Frank Popelka found a job working at Sinclair \& Company while Anna tended to the family's eleven children. ${ }^{26}$ Many of the Popelka children, including Mary and Emma, attended Adams School alongside Emma Oliphant and her older brothers, John and George. ${ }^{27}$ Schools in Cedar Rapids, like its residential neighborhoods, were racially and ethnically mixed. ${ }^{28}$ Other black and Bohemian or Bohemian American girls, like Flora Bouey, Jessie Martin, Maggie Smith, and Annie and Mary Burianek, who would encounter each other a decade later at Liddle \& Carter, also attended Adams School together and lived in Oak Hill. ${ }^{29}$

Cedar Rapids offered real opportunities in areas like education and home ownership. Still, newly relocated working-class families faced social and economic challenges. African Americans who had migrated from the South encountered different but still distinct discrimination in their new northern homes. They were still expected to occupy a subordinate "place" in northern society. Bohemian and other eastern European immigrants also encountered prejudice and discrimination, though their status as "conditionally" or "not quite white" generally put them in an elevated position in comparison to African Americans. ${ }^{30}$

25. Blocker, A Little More Freedom, 49, 81. See also Janette Greenwood, First Fruits of Freedom: The Migration of Former Slaves and their Search for Equality in Worcester, Massachusetts, 1862-1900 (Chapel Hill, NC, 2010), 148.

26. Federal Census (1900); Cedar Rapids City Directories (1895-1901).

27. "Our Schools," Gazette, 9/29/1885.

28. Cools, "The Negro in Typical Communities of Iowa," 95-96. Iowa law banned school segregation on the basis of race in 1868. Clark v. Board of Directors, 24 Iowa 266 (1868).

29. "Our Schools," Gazette, 9/29/1885; Cedar Rapids City Directories (1885-1898).

30. See Karen Brodkin, "Race and Gender in the Construction of Class," Science $\mathcal{E}$ Society 60 (1996/97), 473. See also Matthew Frye Jacobson, Whiteness of a Different Color: European Immigrants and the Alchemy of Race (Cambridge, MA, 1999); 
Many black and Bohemian migrants to Cedar Rapids particularly struggled to secure gainful employment and earn a decent living. Both groups tended to be shunted into some of the least desirable positions. In Iowa, as in many other northern locales, "black men and women were concentrated at the bottom of the occupational ladder," often specifically barred from many trades and industrial employment. The influx of European immigrants exacerbated this already precarious position. Even though blacks were "native-born Americans and English-speaking Protestants" and had more "favorable levels of educational attainment," northern employers "preferred white foreign-born workers (most of them from southern and eastern Europe)." Black men employed as doormen, barbers, waiters, and cooks increasingly found themselves displaced by eastern European immigrant men, while "black women formed an ever larger proportion of laborers in the shrinking fields of hand laundry and personal service" because European "immigrant women continued to find expanded job opportunities in manufacturing." 31

The challenges of finding a decent job were compounded as the wages of most working-class men-even those who landed positions higher on the occupational ladder-consistently fell short of a living wage. Despite increasingly entrenched assumptions that only male heads of households were breadwinners, most working-class families in Cedar Rapids and elsewhere depended on the labor and income of wives and children. ${ }^{32}$ For example, although Frank Popelka and Thomas Oliphant worked

and David Roediger, Working toward Whiteness: How America's Immigrants Became White (New York, 2005).

31. Schwalm, Emancipation's Diaspora, 138; Jones, Labor of Love, Labor of Sorrow, 153, 161, 154.

32. On the family wage ideal and perceptions of men as exclusive wage earners, see Jeanne Boydston, "To Earn Her Daily Bread: Housework and Antebellum Working-Class Subsistence," Radical History Review 35 (1986), 7-25; idem, Home and Work: Housework, Wages, and the Ideology of Labor in the Early Republic (New York, 1994); Nan Enstad, Ladies of Labor, Girls of Adventure: Working Women, Popular Culture, and Labor Politics at the Turn of the Twentieth Century (New York, 1999); Alice Kessler-Harris, A Woman's Wage: Historical Meanings and Social Consequences (Lexington, KY, 1991); idem, Out to Work: A History of Wage-Earning Women in the United States (New York, 1982); Leslie Woodcock Tentler, Wage-Earning Women: Industrial Work and Family Life in the United States, 1900-1930 (New York, 1979); Ava Baron, ed., Work Engendered: 
hard to earn a living, their adolescent and adult children also had to labor to sustain the family. While Frank Popelka worked at Sinclair, his children also found employment: Frank Jr. as a tailor, Amelia and Mary as Liddle \& Carter operatives, Edward as a compositor, Ottilie as a servant, and Julia as a dressmaker's apprentice. In the Oliphant household, Thomas, John, George, and James worked as laborers, while Emma, Bessie, and Anna all worked at various times as domestic servants. ${ }^{33}$

WOMEN'S WAGES were vital to working-class households. The additional income Erie Wood earned by cooking and cleaning for a boarder, as well as her periodic work outside the home as a domestic "day laborer," provided critical economic support for the Wood family. Erie's husband, James, an ex-slave born in Virginia, worked hard as a laborer in Cedar Rapids, but the family needed additional income. James and Erie's 17-year-old daughter Pearl tried to contribute to the family's income by applying for a factory job at Liddle \& Carter. ${ }^{34}$ Several blocks down from the Popelka and Oliphant residences, the Bohemian immigrant Vejda family similarly relied on women's wages. After emigrating from Česká Třebová and settling in Cedar Rapids in the 1880s, head-of-household Kviryn Vejda was only intermittently employed. His Iowa-born daughter Mary remembered that the family constantly scraped by, always forgoing "extras" and most store-bought goods and making bed sheets and pillowcases "out of flour sacks." 35 Kviryn's eldest child, Fannie, who emigrated with her parents, started working outside the home by the time she was 15. After toiling for two years as a domestic servant, Fan-

Toward a New History of American Labor (Ithaca, NY, 1991); Laura Tabili, "Dislodging the Center/Complicating the Dialectic: What Gender and Race Have Done to the Study of Labor," International Labor and Working-Class History 63 (2003), 14-20.

33. Cedar Rapids City Directories (1896-1898); Federal Census (1880, 1900, 1910); "CRB," Bystander, 4/28/1899; "Look! Second Special Announcement about the Gazette's 20th Century Directory," Gazette, 11/11/1899.

34. Iowa State Census (1885); Federal Census (1900); “Jackson School," Gazette, 4/24/1895.

35. "Hemmer Autobiographies," Linn County Historical Society Library and Archives; Federal Census (1900, 1910, 1920). 
nie found a position in the wrapping department of the American Cereal factory in Cedar Rapids, where dozens of immigrant and first-generation women were employed. After a few years working as a "wrapper," Fannie took a job as a laundress at the Parlor City commercial laundry. When she married and left the Vejda household in 1903, her younger sister Mary went to work at a garment factory and gave two-thirds of her weekly earnings to her parents. After her marriage, Fannie continued to work at Parlor City to supplement her husband's income as a railroad car repairman and then a Sinclair employee; by 1910, she was bringing in income by taking in "washing at home" while taking care of her two small children. ${ }^{36}$

Fannie and Mary Vejda, Erie and Pearl Wood, Emma Oliphant, and Amelia, Mary, Emma, Ottilie, and Julia Popelka were among the millions of women in America who were part of the paid labor force in the late nineteenth and early twentieth centuries. In 1890 nearly 20 percent of all women in the United States labored outside the home for wages. ${ }^{37}$ Those working women were often women of color, whose labor force participation was not a new phenomenon, and young immigrant and native-born women of European descent, who were entering the labor force in unprecedented numbers. ${ }^{38}$

In Cedar Rapids, women constituted at least one-fifth of all paid laborers working outside the home around 1900. ${ }^{39}$ An 1898 Cedar Rapids city directory lists nearly 2,000 working women a sample large enough to map overall patterns in women's employment yet specific enough to allow us to trace the working lives of many individual women. And because this directory was

36. "Hemmer Autobiographies"; Federal Census (1900, 1910); “Marriages," Gazette, 9/8/1903; "Man Seriously Injured," Gazette, 12/23/1919; "Beauty Winners," Gazette, 9/23/1921; Iowa State Census (1925); Cedar Rapids City Directories (1890-1905).

37. Claudia Goldin, "Female Labor Force Participation: The Origin of Black and White Difference, 1870 and 1880," Journal of Economic History 37 (1977), 87. See also Joseph A. Hill, Women in Gainful Occupations, 1870-1920, Census Monographs 9 (Washington, DC, 1929), 15, 54; and Lynn Weiner, From Working Girl to Working Mother: The Female Labor Force in the United States, 1820-1980 (Chapel Hill, NC, 1985), 4.

38. Goldin, "Female Labor Force Participation," 87.

39. Census for the State of Iowa (Des Moines, 1905), 604, 216-17. 
produced within just months of the action at Liddle \& Carter and other important women's labor protests in Cedar Rapids, it offers a window into the lives of the specific women involved in those protests. ${ }^{40}$

A few women in Cedar Rapids worked in professional jobs because they wanted to, but the vast majority worked because they had to. They were most often young and unmarried, although plenty of older and married, divorced, or widowed women were also paid laborers. Their employment options were circumscribed by gender - with women being hired for needle, laundry, restaurant, clerical, retail, domestic, and certain kinds of factory work - and then further delineated by race and ethnicity. For example, the 1898 directory sample shows that close to 20 percent of all working women in Cedar Rapids worked in retail, clerical, and secretarial jobs, where white European immigrant and Euro-

40. Help wanted ads and city directories provide extensive information about women's work. Directories offer a particular wealth of information since they were produced annually or biennially and listed the residential address and specific employer and/or occupation of most working-age residents of Cedar Rapids. Because women's work was often overlooked by census takers and often occurred during shorter windows of time than might be captured by decennial censuses, directories allow historians to identify and track women's working lives in a unique way. I accessed the Evening Gazette's Free City Directory of Cedar Rapids, Iowa (Cedar Rapids, May 1898) (hereafter cited as City Directory, 1898) at http://mpl.newspaperarchive.com and then identified all women in the 300-page directory who listed an occupation or employer, a total of 1,888 entries. I then created a database and entered each woman's name, address, occupation, and employer, which allowed me to search, sort, and look for patterns in the data. I was thus able to calculate percentages of women working for particular employers and in various occupations. As research progressed, I added information from other sources (censuses, newspaper articles, and other directories) to this database, adding fields such as race, ethnicity, birthplace, parent's birthplace, age, and marital status. My database findings are subsequently cited as "1898 City Directory Sample and Database." The 1898 directory is also the best available source for identifying the specific women involved in labor protests at Liddle \& Carter and American Cereal in the late 1890s. Because the directory was produced within just months of those actions, it is highly likely that the women listed as working there in the May 1898 directory were also working there during the protests of 1897 and 1898. Newspaper articles, censuses, and other city directories corroborate this for certain women. Since only a handful of women were specifically named in news coverage of the protests, the May 1898 directory sample allows us to identify with confidence, if not absolute certainty, specific women as well as broad characteristics of the groups of women working at Liddle \& Carter and American Cereal during the protests of 1897-1898. 
American women held sway. Similarly, despite black women's long tradition of working in sewing and dressmaking trades, women of European descent predominated among the hundreds of women from the 1898 sample who were engaged as dressmakers, seamstresses, milliners, milliners' assistants, and hat trimmers. ${ }^{41}$

Women working in dining establishments and commercial laundries in Cedar Rapids came from somewhat more diverse backgrounds. Several women - among the 60 total in the sample who cooked and served meals in the city's hotels, restaurants, and lunch stands - worked at Marshall's Restaurant. That restaurant, an institution in downtown Cedar Rapids for more than 40 years, was operated by Marshall Perkins, an African American man, and his German immigrant wife, Louisa. The Perkinses employed black and white men and women as cooks and servers. ${ }^{42}$

Black and white women also worked side by side in commercial laundries in Cedar Rapids, including Parlor City, New Process, Buck's, and Cascade. In total, about 3 percent of all working women in the 1898 sample were engaged in some form of laundry work, with most working for the commercial laundries that had become ubiquitous in urban areas by the 1890s and early 1900s. ${ }^{43}$

41. "1898 City Directory Sample and Database." Professional jobs (teachers, nurses, journalists, physicians, and dentists) constituted 13 percent of the sample (244/ 1,888). Retail, clerical, and secretarial jobs (e.g., clerks, cashiers, bookkeepers, copyists, secretaries, stenographers, telephone operators, etc.) constituted 18 percent of the sample $(331 / 1,888)$. On exclusion of black women from these positions nationally and in Iowa, see Jones, Labor of Love, Labor of Sorrow, 178; and Sally Stevens Cotton, "The Iowa Bystander: A History of the First 25 Years" (M.A. thesis, Iowa State University, 1983), 56. On black women in sewing trades, see Rosalyn Terborg-Penn, "Survival Strategies among African-American Women Workers: A Continuing Process," in Women, Work, and Protest: A Century of US Women's Labor History, ed. Ruth Milkman (Boston, 1985), 148. Dressmakers, seamstresses, milliners, etc., represented 11 percent of the sample $(215 / 1,888)$.

42. "1898 City Directory Sample and Database" (restaurant workers totaled 4 percent of the sample [69/1,888]); Jack Lufkin, "'Higher Expectations for Ourselves': African-Americans in Iowa's Business World," in Outside In, 202-3; "Group portrait ... outside of [Marshall Perkins's] Lunch Room Restaurant," Collections of the African American Museum of Iowa (AAMI), Cedar Rapids; Cedar Rapids City Directories (1890-1910); Federal Census (1880, 1900, 1910, 1920).

43. "1898 City Directory Sample and Database." Laundry workers totaled 60/ 1,888 , with most $(47 / 60)$ working in commercial laundries. See also "LaundryDry Cleaners" folder, Linn County Historical Society Library and Archives. On black women in and the often integrated nature of laundry work, see Goldin, 
For instance, German American sisters Minnie and Lizzie Sallach and Afro-Canadian immigrant Sarah Bouey all worked at New Process during the same period in the late 1890s. ${ }^{44}$ Commercial laundry work was hot, damp, and physically demanding; a Des Moines News article explained that it often led to a "life of aches" and ailments for women workers. ${ }^{45}$

Even so, many women found laundry work preferable to the primary alternative of domestic service, as it offered somewhat more autonomy and the opportunity to work alongside female friends or family members. At New Process, sisters Minnie and Lizzie Sallach worked with each other, as did mother and daughter Sarah Flora Bouey. The Bouey women went out to work following the death of their husband/father William in 1892. Initially, only Sarah worked at New Process, while 19-year-old Flora and her 12-year-old brother Edmund supplemented their mother's income by teaching music lessons and delivering newspapers. By 1897, however, Sarah and the children were struggling to get by, perhaps in part because black laundresses were paid less than white ones. 46

Even if Sarah Bouey was paid the same wages as the Sallach sisters, her family would have found it nearly impossible to get by exclusively on the wages of one working woman. According to government reports, annual earnings for men in midwestern cities around 1890 averaged between $\$ 560$ and $\$ 630$, while women's averaged between $\$ 200$ and $\$ 330$. In 1900, the median national weekly wage for men was $\$ 10.55$ (close to $\$ 550$ per year, if one worked steadily all year) while women's was $\$ 5.64$ (around $\$ 290$

\footnotetext{
"Female Labor Force Participation," 96-97; Carter Woodson, "The Negro Washerwoman," Journal of Negro History 25 (1930), 269-77; Elizabeth Haiken, "The Lord Helps Those Who Help Themselves: Black Laundresses in Little Rock, Arkansas, 1917-1921," Arkansas Historical Quarterly 49 (1990), 20-50.

44. Federal Census $(1900,1910)$; “Last Installment of Names for the Gazette's 20th Century Directory," Gazette, 11/18/1899; Cedar Rapids City Directories (1896, 1907).

45. “Women Laundry Workers Lead Life of Aches," Des Moines News, 10/11/ 1916; Jones, Labor of Love, Labor of Sorrow, 178.

46. Federal Census (1880, 1900, 1910); Cedar Rapids City Directories (1892-1898, 1900, 1907); "Free Directory of Cedar Rapids, Marion, and Kenwood," Gazette, 10/22/1896; Jones, Labor of Love, Labor of Sorrow, 178; Haiken, "The Lord Helps Those Who Help Themselves," 33.
} 


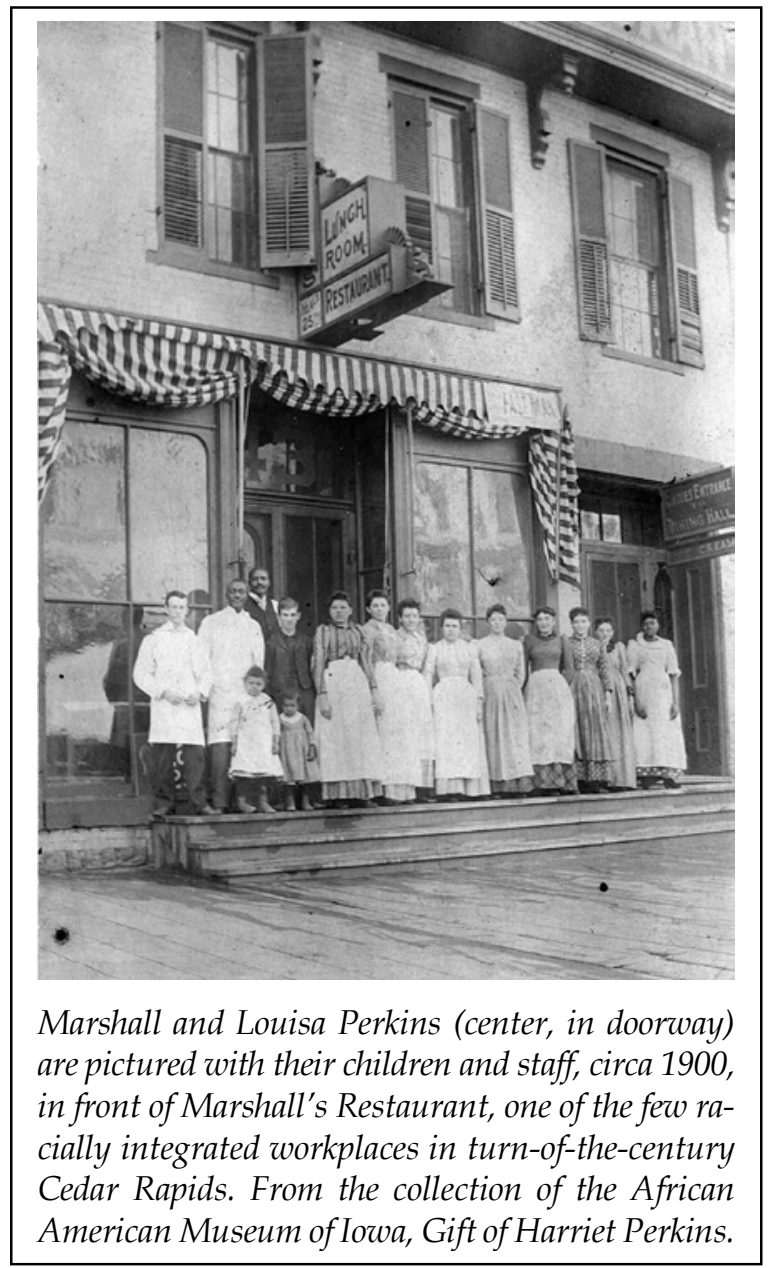

for the year). From the 1890s to 1910s, most working women in Cedar Rapids earned even less than that, typically pulling in just $\$ 2$ to $\$ 5$ a week, or about $\$ 100$ to $\$ 250$ per year. Yet, around the turn of the century, "an annual salary of $\$ 800$ was considered the minimum necessary for survival for a family of four." 47 Sarah

47. Elyce J. Rotella, From Home to Office: U.S. Women at Work, 1870-1930 (Ann Arbor, MI, 1981), table B.1; Edith Abbott, Women in Industry: A Study in American Economic History (New York, 1910), 312; "Condition of Labor," Gazette, 9/27/ 1894; Mary Allison Farley, "Iowa Women in the Workplace," Palimpsest 67 (1986), 11; "Servant Girls," Gazette, 5/8/1890; "Still Out," Gazette, 10/24/1898; 
Bouey's New Process wages surely would have fallen well short of that cost of living, which likely factored in Flora's decision to set aside her aspirations to be a musician and find a job that was more lucrative than the occasional music lesson. Although she was a "talented" piano player and a "student of the conservatory of music," Flora attempted to get a job at Liddle \& Carter in 1897 and ultimately went to work alongside her mother at New Process. ${ }^{48}$

Laundry work was grueling, but still many women preferred it to domestic service - the most common occupation for women in turn-of-the-century Cedar Rapids. Nearly 500 women in the 1898 sample - at least a quarter of all women working outside the home in the city - were employed as domestic servants. ${ }^{49} \mathrm{Na}-$ tionally, the percentage was even higher; in 1900, about a third of all working women were domestics. Government reports noted that between 1880 and 1920 domestic service "steadily [lost] ground in its relative importance as an occupation for [white] women." The movement of native-born and immigrant white women into clerical, sales, and manufacturing jobs "left an increasing proportion of black women to scrub floors, make beds, and cook meals for employers." In the South, domestic positions were occupied exclusively by black women. In the Midwest, Scandinavian and central European women tended to predominate, although plenty of Irish and African American women also worked as domestics. ${ }^{50}$ Emma Oliphant and other black women in Cedar Rapids tended to only find positions as domes-

Mary Vejda record in Iowa State Census (1915); Nancy J. Barrett, “The Struggles of Women Industrial Workers to Improve Work Conditions in the Progressive Era," OAH Magazine of History 13 (1999), 43.

48. "Session Closed. Conference of St. Paul District A.M.E. Churches," Gazette, 5/20/1897; Cedar Rapids City Directory (1900); Federal Census (1900).

49. "1898 City Directory Sample and Database." Of the sample, 472/1,888 women (25 percent) were "domestics." If we include all cleaning and domestic-type work (e.g., maid, housekeeper, janitress), the figure rises to $523 / 1,888$ (28 percent).

50. Hill, Women in Gainful Occupations, 36; Jones, Labor of Love, Labor of Sorrow, 132; Stephen Gross, "Domestic Labor as a Life-Course Event: The Effects of Ethnicity in Turn-of-the-Century America," Social Science History 15 (1991), 409. On northern black women and domestic work, see Schwalm, Emancipation's Diaspora, 138-40; Ralph Scharnau, "African-American Wage Earners in Iowa, 18501950," in Outside In, 217-18, 237; Kathryn M. Neal, "Unsung Heroines: AfricanAmerican Women in Iowa," in Outside In, 367; and Jones, Labor of Love, Labor of Sorrow, 164. 
tics. Oliphant's first documented job outside the home was as a "domestic," and she, like many working-class women in Cedar Rapids, jumped from one domestic job to another. ${ }^{51}$ Domestic jobs were always easy to come by, but low pay and high expectations led to tremendous turnover. As a Gazette article observed, employers "routinely find fault, follow their servant in their work and are never satisfied." "If a girl can secure any other employment, even if the remuneration is less," the article concluded, "she will accept it in preference to domestic duties." 52

FACTORY WORK offered an appealing alternative to domestic service. About 15 percent of all working women in the 1898 sample, second only to domestic service, worked in the city's factories, most notably Cedar Rapids Box Company, Cedar Rapids Candy Company, National Cracker Company, Sinclair \& Company, farm equipment manufacturer J. G. Cherry Company, American Cereal, and Liddle \& Carter. The majority worked as wrappers at American Cereal or as garment workers at Liddle \& Carter. 53

For those who could secure them, factory jobs were among the best jobs available to working-class women, offering some of the highest wages. As a Gazette article explained, "girls" working in factories and other "occupations more congenial" typically earned "more than [the] \$1 or \$2 a week" paid to domestic servants. According to one historian's estimate, female factory workers in the Midwest could earn an average of about $\$ 5$ per week. In the late 1890s, wrappers at American Cereal earned 14 cents for every 100 packages of cereal they wrapped, which theoretically made it possible to earn as much as $\$ 1.40$ per day ( $\$ 6$ to $\$ 8$ per week); yet, as one worker explained, "even the best and most

51. Cedar Rapids City Directories (1896-1901); Federal Census (1900).

52. "Servant Girls," Gazette, 5/8/1890.

53. "1898 City Directory Sample and Database" (289/1,888). This figure would be even higher $(308 / 1,888)$ if we included women in the printing industry. Liddle \& Carter was listed as the employer of 53 women in the sample-two of whom were "bookkeepers" (and thus excluded from the industrial workers tally). That number aligns closely with the reference to "seventy skilled employees" in newspaper coverage of the color line confrontation. The directory listed 119 women working at American Cereal. Removing a few duplicate names and clerical or other non-manufacturing positions left about 110 women working as wrappers. 
industrious of us wrappers are not making much more than $\$ 2$ a week on average." 54

Garment factories offered similar wages, with entry-level operatives at Liddle \& Carter earning perhaps $\$ 2$ to $\$ 4$ per week in the 1890s, with a few experienced seamstresses making two or three times that. ${ }^{55}$ However, the seasonal nature of the garment industry meant that workers were routinely laid off for weeks and months at a time. ${ }^{56}$ For example, when federal census takers knocked on the door of the Popelkas' residence in June 1900, Amelia - a garment worker at the Liddle \& Carter "overall fct" had already been out of work for three months of the year; Amelia's coworker Emma Kozak, who "makes overalls" at Liddle \& Carter, had not worked at all. Kozak and Popelka, along with other Cedar Rapids garment workers like Mary Vejda and sisters Pearl, Mary, and Agnes Langer, were all laid off on numerous occasions and for months at a time. After layoffs and slow periods are considered, a typical female garment factory worker in Cedar Rapids in the 1910s earned just \$250 per year-nowhere close to the cost of living at the time. ${ }^{57}$

Even so, factory jobs were among the highest-paying and most desirable jobs for working-class women in Cedar Rapids. They were harder to come by in the first place, with fewer positions available compared to domestic service and laundry work,

54. "Servant Girls," Gazette, 5/8/1890; Kyle E. Ciani, "Hidden Laborers: Female Day Workers in Detroit, 1870-1920," Journal of the Gilded Age and Progressive Era 4 (2005), 23-24, 33; "Still Out," Gazette, 10/24/1898.

55. Based on figures reported by female operatives working in Cedar Rapids garment factories, circa 1910-1920. In 1912 most women earned \$3 to \$6 per week while experienced seamstresses made as much as $\$ 10$ to $\$ 15$ per week. In 1920 entry-level workers at Welch-Cook made \$6 per week. "Hemmer Autobiographies." See also Farley, "Iowa Women in the Workplace"; and Jones, Labor of Love, Labor of Sorrow, 167.

56. Busy seasons fell in the spring and late summer-fall, precisely the time when Liddle \& Carter repeatedly advertised for operatives in August 1897. During other parts of the year, "virtually no work was available." Roger Waldinger, "Another look at the International Ladies' Garment Workers' Union: Women, Industry Structure and Collective Action," in Women, Work, and Protest, 92.

57. Federal Census (1900); Cedar Rapids City Directory (1903); Iowa State Census (1905); Mary Vejda record in Iowa State Census (1915); "Hemmer Autobiographies"; Abbott, Women in Industry, 312; Weiner, From Working Girl to Working Mother, 25. 
and turnover less common. ${ }^{58}$ Most of the wrappers at American Cereal and the female operatives at the Liddle \& Carter and Welch-Cook garment factories worked there for years. When factory women did seek out a new job, they tended to move to another factory job rather than returning to domestic service. Fannie Vejda was just one of many wrappers who abandoned domestic service in order to take a job at American Cereal. Seventeen-year-old Bohemian immigrant Agnes Langer moved between jobs in at least three different Cedar Rapids factories within the space of less than a year rather than return to domestic service. After landing the job at American Cereal, Agnes continued to work as a wrapper for several years. Agnes's older sister Pearl also jumped between factory jobs. After working at Liddle \& Carter for years, Pearl, by 1900, had moved 60 miles north to Cedar Falls to take a position as an "operator in overhaul [sic] fcty" in that city. ${ }^{59}$

Female factory workers in Cedar Rapids came from similar ethnic and racial backgrounds. More than 80 percent of the wrappers at American Cereal in 1898 and close to 90 percent of the female operatives at Liddle \& Carter were European immigrants or the daughters of European immigrants - a figure that corresponds to the findings of historians looking at other cities. ${ }^{60}$ In

58. Based on a survey of all Gazette want ads for women's jobs published on one day in each of six months (January, March, May, July, September, and November) in 1888, 1898, 1908, and 1918. Domestic jobs were the most commonly advertised job in each of those months and years.

59. Cedar Rapids City Directories (1898-1903); Federal Census (1900).

60. "1898 City Directory Sample and Database." Of the 110 American Cereal wrappers, I was able to definitively document the birthplaces of 79 women and their parents. Of the 79, 19 (24 percent) were immigrants, 45 (57 percent) were the daughters of immigrants, and 15 (19 percent) were native born to nativeborn parents. The birthplaces and parents' birthplaces of 40 of the 51 female operatives at Liddle \& Carter could be determined. Of the 40, 9 (22.5 percent) were immigrants, 26 (65 percent) were the daughters of immigrants, and 5 (12.5 percent) were native born to native-born parents. Nationally, about 75 percent of all female factory workers at the end of the nineteenth century were foreign born or the daughters of foreign-born immigrants. Barrett, "The Struggles of Women Industrial Workers," 43. One study of garment workers in Chicago found that 65 percent were foreign born and another 32 percent were first-generation immigrants. N. Sue Weiler, "The Uprising in Chicago: The Men's Garment Workers Strike, 1910-1911," in A Needle, A Bobbin, A Strike: Women Needleworkers in America, ed. Joan M. Jensen and Sue Davison (Philadelphia, 1984), 117. 
particular, a quarter of the female workers at American Cereal and Liddle \& Carter were European immigrants. About another 60 percent at each factory had been born in the United States to parents who had recently emigrated from places like Germany, Ireland, and especially Bohemia. Indeed, 60 percent of the wrappers and 75 percent of the Liddle \& Carter operatives came from a Bohemian background. ${ }^{61}$

While Bohemian women predominated, African American women were excluded from industrial jobs. No black women in the 1898 sample were employed in Cedar Rapids factories. Nationally, "less than three percent of all black working women were engaged in manufacturing" in 1900, as "compared with 21 percent of foreign-born and 38 percent of native-born white working women." 62 In the 1890s, the color line in women's factory work was clear - a fact women like Emma Oliphant sought to change.

THE DECISION to attempt to break the color line at Liddle \& Carter was first sparked by the women's desires to materially improve their families' incomes and economic positions. The lack of decent employment options for black women was a major concern for the women, just as it was for more prominent black activists in the 1890s. In an address at the World's Columbian Exposition in Chicago in 1893, Fannie Barrier Williams explained that "except teaching in colored schools and menial work, colored women can find no employment in this free America." Closer to home, a major focus of the editorial coverage of the Iowa State Bystander - the state's leading African American newspaper - in the mid-1890s was "the lack of diversification of jobs for

61. "1898 City Directory Sample and Database." On Bohemians in the garment industry, see Weiler, "The Uprising in Chicago," 117-18, 134.

62. Jones, Labor of Love, Labor of Sorrow, 166. On the exclusion of blacks in manufacturing, see Terborg-Penn, "Survival Strategies," 147; Joe Trotter Jr., "African Americans and the Industrial Revolution," OAH Magazine of History 15 (2000), 19-23; Larry J. Griffin and Robert R. Korstad, "Class as Race and Gender: Making and Breaking a Labor Union in the Jim Crow South," Social Science History 19 (1995), 425-54; Kimberley Phillips, “'But It Is a Fine Place to Make Money’: Migration and African-American Families in Cleveland, 1915-1929," Journal of Social History 30 (1996), 393-413. 
black people"; black women "had received good educations," its editors noted, but "never seemed to have a chance for a job." 63

All of the black women who applied at Liddle \& Carter could have benefited substantially from increased income. Peal Wood and Jessie Martin were young women in their teens who worked outside the home to supplement the income of households that always seemed to struggle to get by. ${ }^{64}$ By the summer of 1897, many of the women had new and pressing economic concerns. The Oliphant family experienced significant upheavals in the mid-1890s when Thomas became an invalid. Although Anna received a modest Civil War veteran's widow's pension after Thomas's death in 1896, that was not enough to support the family. ${ }^{65}$ After 1896, the Oliphant children's income became even more critical; John, George, and Emma - along with their mother, Anna - all had to work outside the home in order to make ends meet. By the summer of 1897, when Emma decided to apply at Liddle \& Carter, the family's struggles undoubtedly would have been on her mind.

By the late 1890s, Mattie Price, Sarah and Flora Bouey, and Mary Bowlin were also dealing with the loss of their primary male breadwinners. Households that suffered the loss of a husband and father to death, divorce, or abandonment were particularly vulnerable to economic hardship. In the 1880s and early 1890s, Mattie Price was married to a successful barber and spent her days "keeping house" and looking after the couple's two children. ${ }^{66}$

63. Fannie Barrier Williams, as quoted in Shirley Wilson Logan, “'What Are We Worth: Anna Julia Cooper Defines Black Women's Work at the Dawn of the Twentieth Century," in Sister Circle: Black Women and Work, ed. Sharon Harley et al. (New Brunswick, NJ, 2002), 157; Cotton, "The Iowa Bystander," 56.

64. Cedar Rapids City Directories (1895-1900); Federal Census (1880, 1900, 1910).

65. "Civil War Pension Index" (accessed via ancestry.com); Federal Census (1900); "Soldier Dead of Two Wars in Linwood, Kenwood, and Oak Hill," Gazette, $5 / 27 / 1899$.

66. The exact identity of the "Mattie Price" listed as one of the seven African American women who sought to work at Liddle \& Carter has been difficult to confirm definitively, but most evidence suggests that she was Mrs. Mattie Price, wife of barber Richard Price, who often associated with Mattie Wade and other women involved in the protest, as indicated in the Iowa State Bystander's "CRB" columns in the 1890s. "Mrs Mattie Price, wid Richard" continues to appear in Cedar Rapids directories until the 1910s. Cedar Rapids City Directories (18901910); Federal Census (1880). It is possible that the "Mattie Price" listed in the 
By 1896, however, she was a widow with two teenaged children and on her own financially, which means she may have needed to work for wages. Sarah and Flora Bouey certainly understood that situation, as did their New Process coworkers the Sallach sisters - who offer an instructive example of how financially difficult things could be for female-headed households. German immigrant and recent widow Elizabeth Sallach relied on the wages of her four working daughters: Lizzie and Minnie, who worked at New Process; Emma, who worked at Buck's Laundry; and Mary, who worked as a housekeeper. With the combined wages of the four young women working full time, the Sallachs probably managed to get by on $\$ 15$ per week - about what one workingclass man made. ${ }^{67}$ Mary Bowlin, a friend of the Bouey women, also unexpectedly became responsible for supporting her family. Mary first moved to Cedar Rapids in the early 1880s to be with her newly married older sister, Hattie Raspberry. A few years later, Mary married Walter Bowlin, a barber from a well-established black family in Cedar Rapids. When the couple's strained relationship ended by 1889, Mary had to support herself and young Walter Jr., born in 1886. For at least the next five years she worked as a domestic. Several of these positions were live-in domestic jobs, which may have offered Mary steadier and betterpaying work than day labor but surely impinged on her time with her own family. By 1897, she must have relished the prospect of better wages, more preferable hours, and the possibility of living at home with her son that a factory job at Liddle \& Carter offered. ${ }^{68}$

Mattie Wade, Mary Bowlin's friend and Sarah Bouey's immediate neighbor, also seems to have had concerns about supporting

1897 Liddle \& Carter articles was "Minnie Price," who would have been about 17 at the time of the protest, or "Attie" (or "Addie") Price, who was in her late teens in the 1890s and friends with Emma Oliphant. Cedar Rapids City Directories (1890-1910); Iowa State Census (1885); Federal Census (1900); “CRB," Bystander, 6/18/1897, 12/23/1898, 12/22/1899.

67. Federal Census (1900); "Last Installment of Names for ... Directory," Gazette, $11 / 18 / 1899$.

68. "Walter H. Bowlin Married," Gazette, 6/24/1885; "Marriages, Births and Deaths," Gazette, 7/27/1886; "Inhuman Beings: The Dastardly Treatment Administered to a Little Colored Boy," Gazette, 1/7/1889; Cedar Rapids City Directories (1895, 1896, 1898, 1900, 1906); Federal Census (1900). Mary's last name was sometimes spelled "Bowling" in these records. 
her family. In the 1890s, Wade was a married mother of four who was never documented in census or directory records as working outside the home. Unlike in the South, where the vast majority of black women, married as well as single, were employed, very few married black women in Cedar Rapids worked outside the home. ${ }^{69}$ And yet Mattie Wade was among the seven women who sought a job at Liddle \& Carter in 1897, perhaps due to changes in her husband George's occupation from "reverend" to "laborer" and "janitor." The Wades had no children of working age who could add to the family earnings, and Mattie was occupied with having and raising children. By 1897, however, their eldest child would have been almost 13 and the youngest 3 , which might have made it possible for Mattie to consider going out to work. ${ }^{70}$

WHILE the women's decisions to apply at Liddle \& Carter were motivated by real economic concerns, they were also very consciously protesting racial discrimination. As Jacqueline Jones observes, black men and women "tended to understand, in a way their white counterparts did not, that 'racial' injustice was inextricably linked to economic injustice." "Civil rights struggles," adds historian Kevin Gaines, "are seldom just about race but invariably involve class" - and, we should add, gender "identities and conflicts." 71

The seven protesting women lived within blocks of each other in Oak Hill in the late 1890s, knew each other well, and had some experience with collective activism prior to August $1897 .{ }^{72}$

69. Victoria Wolcott, Remaking Respectability: African American Women in Interwar Detroit (Chapel Hill, 2001), 23.

70. Federal Census (1900); Cedar Rapids City Directories (1895-1898); “Last Installment of Names for . . . Directory," Gazette, 11/18/1899.

71. Jones, "Race and Gender in Modern America," Reviews in American History 26 (1998), 230; Kevin Gaines, "Rethinking Race and Class in African-American Struggles for Equality, 1885-1941," American Historical Review 102 (1997), 381.

72. I also suspect, but have not been able to definitely prove, that Flora Bouey and Pearl Wood were relatives. The Wood and Bouey families often lived at the same residences in the years surrounding the turn of the century, sharing or alternating residences at 1015 10th Avenue and 1729 South 8th Street. Sarah Bouey and Erie Wood were also both born in Canada, which may indicate that they were sisters. Federal Census (1900, 1910); Cedar Rapids City Directories (1895-1905). 


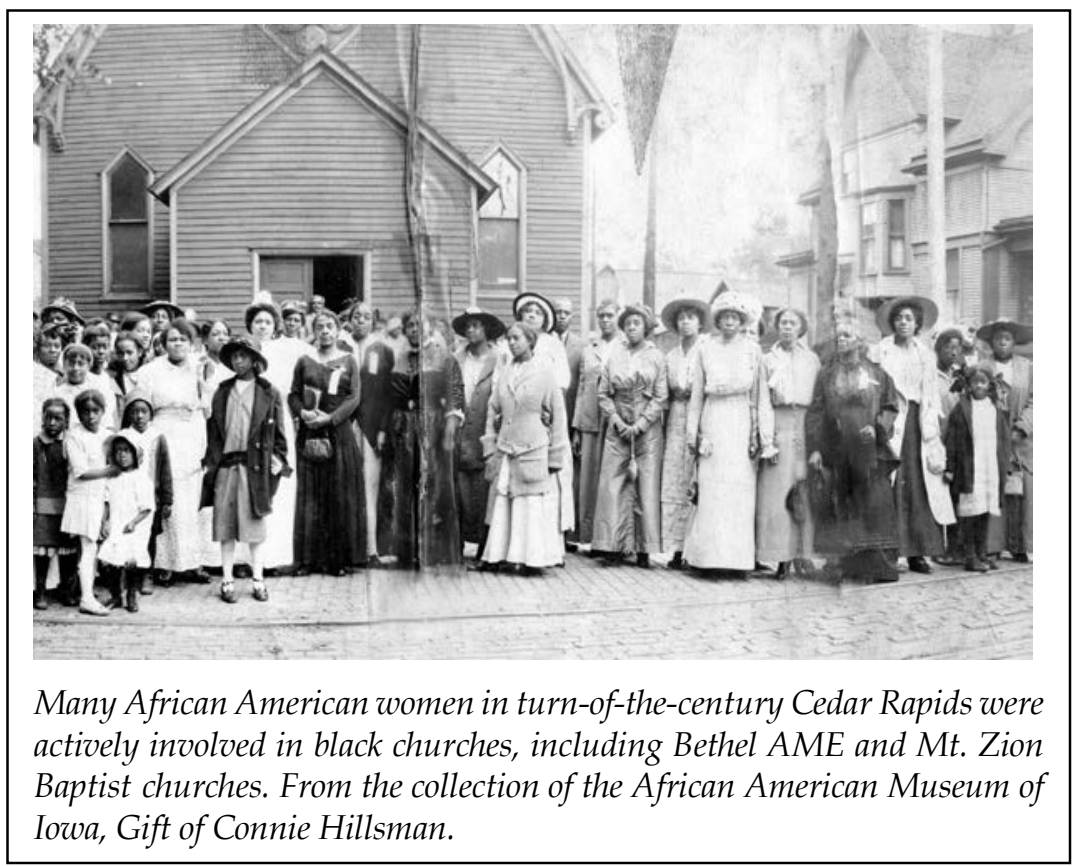

The women spent time together over the course of several years socializing and participating in the same clubs, churches, activities, and hobbies. Their social lives were extensively chronicled in the Bystander, probably because Mattie Wade produced the "Cedar Rapids Budgetarian" column that reported the activities of black men and women in the city. ${ }^{73}$ Oliphant, Wade, Bouey, Bowlin, and Martin were all active in the Bethel African Methodist Episcopal (AME) Church in Cedar Rapids. ${ }^{74}$ Their work in the church probably gave the women their first experiences with activism and organizing. Black churches in the nineteenth and twentieth centuries served not only as important religious ref-

73. “CRB,” Bystander, 12/23/1898, 6/18/1897, 12/22/1899, 5/5/1899, 6/29/1900; "Correspondents and Agents," Bystander, 6/28/1895.

74. “Colored Endeavors," Gazette, 6/3/1897; “CRB," Bystander, 11/26/1897, 12/10/1897, 12/17/1897, 3/3/1899, 4/28/1899, 8/10/1900; "Session Closed. Conference of St. Paul District A.M.E. Churches," Gazette, 5/20/1897. On the history of the church, see Schwalm, Emancipation's Diaspora, 144; Frances E. Hawthorne, "The Church," in Outside In, 391; and Marlee Jessop, "Iowa's Black Churches," www.blackiowa.org/education/black-history-moments/iowas-blackchurches. 
uges but were critical in fostering community bonds, black social assistance programs, and civil rights activism. ${ }^{75}$ Some scholars have even identified important connections between black churches and women's labor activism. ${ }^{76}$

Most of the Liddle \& Carter women socialized together and were involved in the same events and activities. Emma Oliphant, Flora Bouey, Mattie Wade, and Jessie Martin particularly spent a lot of time together. They went on picnics, attended luncheons and barbeques, threw surprise parties for each other, hosted fashionable "early Sunday morning breakfasts," enjoyed dinners, "games and social chats" in each other's homes, and "attended the opera" in downtown Cedar Rapids. ${ }^{77}$ Wade and Bouey enjoyed acting together in theatrical productions; Wade, Bouey, and Oliphant shared a love of music; and Wade and Bowlin took art lessons together. ${ }^{78}$

The women also participated in clubs and societies, the importance of which has been widely documented by historians. ${ }^{79}$

75. Hawthorne, “The Church," 387-401; Andrew Billingsley, Mighty Like a River: The Black Church and Social Reform (New York, 1999); C. Eric Lincoln, The Black Church in the African American Experience (Durham, NC, 1990); R. Drew Smith, From Every Mountainside: Black Churches and the Broad Terrain of Civil Rights (Albany, NY, 2013).

76. Mary Frederickson, "'I Know Which Side I'm On': Southern Women in the Labor Movement in the Twentieth Century," in Women, Work, and Protest, 163; Terborg-Penn, "Survival Strategies," 143-44.

77. “CRB,” Bystander, 5/14/1897, 5/12/1899, 7/6/1900, 12/30/1898, 6/18/1897, 12/17/1897, 7/30/1897, 4/29/1898, 9/2/1898, 9/10/1897, 5/5/1899, 12/22/ 1899, 8/10/1900, 9/12/1897; “In Matrimonial Bonds," Cedar Rapids Republican (hereafter cited as Republican), 11/21/1901; "Iowa Federation in Session Here; Colored Women's Club Representatives Convene," Gazette, 5/23/1904.

78. "Colored Endeavors," Gazette, 6/3/1897; "Story of the Nile: The Long Expected Egypta on the Stage," Gazette, 11/27/1894; "CRB," Bystander, 11/26/ 1897,3/3/1899, 4/28/1899, 8/10/1900.

79. Schwalm, Emancipation's Diaspora, 197-200; Neal, “Unsung Heroines,” 368-70; Anne Beiser Allen, "Sowing the Seeds of Kindness and Change: A History of the Iowa Association of Colored Women's Clubs," Iowa Heritage Illustrated 83 (2002), 2-13; Richard Breaux, "'Maintaining a Home for Girls': The Iowa Federation of Colored Women's Clubs at the University of Iowa, 1919-1950," Journal of African American History 87 (2002), 236-56; Anne Meis Knupfer, Toward a Tenderer Humanity and a Nobler Womanhood: African American Women's Clubs in Turn-of-the-Century Chicago (New York, 1996); Elizabeth Lindsay Davis, Lifting as They Climb (New York, 1996); Wanda A. Hendricks, Gender, Race, and Politics in the Midwest: Black Club Women in Illinois (Bloomington, IN, 1998); White, Too Heavy a Load. 
The Bystander recorded these activities and, although the city's white-run newspapers rarely covered the activities of black people, the Gazette noted that Emma Oliphant had helped to organize many societies aimed at doing "much good" in the community. ${ }^{80}$ Wade, Martin, Oliphant, and other members of the black community regularly attended club and society meetings in each other's homes. The Ladies Industrial Circle, for example, was described as "doing grand work," which seems to have included everything from "programs" to fishing to quilting. Many of the women were also members of the Light House Society, a mixedgender group that prepared "excellent programmes" consisting of "readings, papers, and discussion" on current events, literature, and history - some of which focused on black history and political issues. ${ }^{81}$

Notably, some of these women and their families were also involved with annual Emancipation Day celebrations in turn-ofthe-century Cedar Rapids. ${ }^{2}$ The celebrations were organized by those with personal connections to slavery and black military service in the Union Army during the Civil War. Immediate connections to slavery could be found among the families of most black residents of Cedar Rapids, including the Oliphants, Boueys, Woods, Martins, and Bowlin/Raspberrys. ${ }^{83}$ Organizing and attending Emancipation Day celebrations honored that history. The events also reminded whites living in the age of Jim Crow of the important roles African Americans played during the Civil War, the true meaning of that war as being about abolition and freedom, and the patriotism and citizenship of black people. ${ }^{84}$

80. "Colored Endeavors," Gazette, 6/3/1897.

81. “CRB," Bystander, 3/26/1897, 4/29/1898, 8/19/1898, 7/23/1897, 7/30/1897, 12/17/1897, 9/9/1898, 11/16/1900.

82. “Colored Men Celebrating Emancipation Day," Gazette, 8/4/1897; “Emancipation Celebration," Bystander, 9/8/1899.

83. On slavery as a linking factor among northern black migrants, see Greenwood, First Fruits of Freedom, 172; and Schwalm, Emancipation's Diaspora, 135.

84. David Blight, Race and Reunion: The Civil War in American Memory (Cambridge, MA, 2001); Leslie Schwalm, "Emancipation Day Celebrations: The Commemoration of Slavery and Freedom in Iowa," Annals of Iowa 62 (2003), 291-332. 
These personal and community ties informed and motivated the women's collective action at Liddle \& Carter. In addition to factors like gender, race, and class, "family and community ties" have a fundamental "bearing on the consciousness and labor activity of both women and men-indeed, on the development of an entire labor community." 85 We see this not only among the seven Liddle \& Carter women but also in their ties to other African Americans who were challenging the color line in employment in Cedar Rapids in the 1890s.

The women seem to have coordinated their protest with William Raspberry, a prominent figure in black and organized labor circles in Cedar Rapids. He was Mary Bowlin's brother-in-law, and he knew Emma Oliphant, Mattie Wade, Flora Bouey, and the other protestors very well through the AME Church, Light House Society, Emancipation Day celebrations, and other clubs and activities. $86 \mathrm{He}$, too, was frustrated by what it meant to be black and working class. As he told the press, "It will be so in a short time that a colored man cannot get anything to do in Cedar Rapids." ${ }^{77}$ During the turmoil with Liddle \& Carter, Raspberry served as the women's public spokesman. ${ }^{88}$

The women also knew Eva Broadie, another young black woman pushing against the color line in women's factory work. ${ }^{89}$ Within just two weeks of the confrontation at Liddle \& Carter, the Bystander intriguingly reported that "Miss Eva

85. Carole Turbin, “Reconceptualizing Family, Work, and Labor Organizing: Working Women in Troy, 1860-1890," in Hidden Aspects of Women's Work, ed. Christine Bose, Roslyn Feldberg, and Natalie Sokoloff (New York, 1987), 18386. For excellent examples, see Ardis Cameron, "Bread and Roses Revisited: Women's Culture and Working-Class Activism in the Lawrence Strike of 1912," in Women, Work, and Protest; Hunter, To 'Joy My Freedom; and Elizabeth ClarkLewis, Living In, Living Out: African American Domestics in Washington, DC, 19101940 (Washington, DC, 1994).

86. "Personal," Gazette, 8/5/1896; "Aditional [sic] Personal and Local," Gazette, 10/21/1896; "The Eagles Celebrate in Good Old-Fashioned Style," Gazette, 7/4/1902; “Mrs. Laura Raspberry,” Gazette, 2/17/1904; “CRB,” Bystander, 7/30/ 1897, 9/9/1898, 11/18/1898.

87. "Threatened to Strike," Gazette, 9/2/1897.

88. "Color Line," Gazette, 9/4/1897; “Not the Foreman; Henry [sic] Raspberry Objects to a Title Which Is Not His Own," Gazette, 9/20/1897.

89. Alison Givens and Kyleigh Munkel, "The Broadie Family," unpublished research paper, Coe College, April 2014. Broadie seems to have been particularly good friends with Emma Oliphant. 
Broadie is the only Afro-American young lady working in the oat meal mill." 90 That brief two-line reference is the only clear record of Broadie's or any black woman's employment in a Cedar Rapids factory during this period. ${ }^{91}$ Thus, in the late summer and fall of 1897, Emma Oliphant may have had good reason to believe that similar success at Liddle \& Carter was within reach. Month after month publications like the Bystander "posted news of the "color line' as it was drawn locally as well as nationally," reporting on "black successes in 'breaking through" as well as "further entrenchments of the hated 'line.' "92

YET when events unfolded on the shop floor at Liddle \& Carter on that Thursday in September 1897, Oliphant and the other black women encountered another group of working women who were not about to see that line redrawn in "their" workplace. During the heated and personal confrontation, the black women ran headlong into just how deeply entrenched racial discrimination and segregation were - even in Iowa, which was less overtly racist than the South, and even among other working-class women they had known personally for many years. As with the black women, personal connections and a shared sense of themselves as white laboring ladies formed the foundation of solidarity and labor activism among the existing workers at Liddle \& Carter.

90. “CRB," Bystander, 9/17/1897. Broadie most likely worked in the wrapping department, as that was where almost all female workers were concentrated in the late 1890s.

91. I found no other evidence in the Bystander, Gazette, city directories, or census data about Broadie's employment at the mill. After consulting directories, censuses, photographs of female factory workers, and many newspapers, I found no other evidence of black women's factory employment in Cedar Rapids during this period - with the exception of some references in the Bystander to the fact that "quite a number of our people received positions in the new canning factory" in Cedar Rapids. Bystander, 9/2/1898. It is unclear, however, whether this included women as well as men. See also Gazette, 9/1/1898 and 9/2/1898 (though these articles make no mention of black workers at the canning factories). Major Cedar Rapids factories like Quaker Oats, Sinclair \& Company/Wilson's, and Penick and Ford (formerly Douglas Starch Works) began to employ black men in the early 1900s and particularly from World War I onward. “Towns - Cedar Rapids \#2," vertical files, AAMI; Bergmann, The Negro in Iowa, 64.

92. Cotton, "The Iowa Bystander," 104-5. Notably, columns on "the success of the colored race" often appeared right next to "CRB" columns listing the protesting women's social activities. See, for example, Bystander, 3/26/1897. 


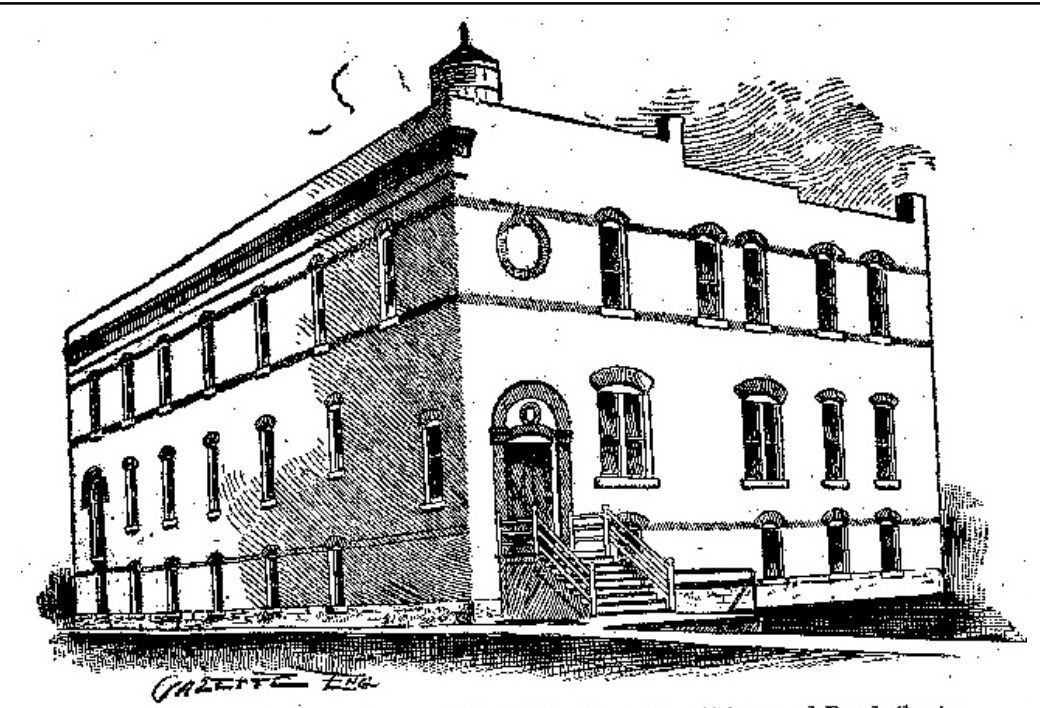

Where Liddle \& Carter make Valley City Overalls, Shirts and Duck Coats.

\section{LIDDLE \& GFRTER, - ZUbolesale hotions and Furnisbing Goods.} CEDAR RAPIDS, IOWA. MANUFACTURERS OF VALLEY CITY OVERALLS, PANTS, SHIRTS, ETC.

The Liddle \& Carter garment factory in Cedar Rapids, as it appeared at the time of the confrontation between black and white women workers. Advertisement from The Evening Gazette's Free City Directory of Cedar Rapids, Iowa, May 1898. Republished with permission (C) 2015 Iowa SourceMedia Group, Cedar Rapids, Iowa.

Because nearly 90 percent of the female operatives at Liddle \& Carter were either European immigrants or the daughters of European immigrants - with 75 percent being Bohemian -it is perhaps not surprising that many of the operatives knew each other very well; indeed, they were relatives, friends, and neighbors. Many-including Mary and Amelia Popelka, Pearl and Mary Langer, Mary and Emma Kozak, Annie and Mary Prochaska, and Annie, Frances, and Mary Kuda-were actual sisters, as well as shop-floor sisters. According to the 1898 sample, 40 percent of the female garment workers at Liddle \& Carter labored alongside at least one sister. Even if they were not related, 
many of the operatives lived in the same neighborhoods; about a fifth of them lived near each other on C Street West, in the area known today as Czech Village. Most were Bohemian or Bohemian American, although Lulu Dulin and Della Brown, who were native born to native-born parents, also lived on this small stretch of C Street West. Other Liddle \& Carter workers, including the Popelka sisters and Bohemian American Mamie Kolarik, lived in the Oak Hill neighborhood on South Tenth and South Ninth streets - right by Mattie Wade, Mary Bowlin, Jessie Martin, and Flora Bouey. ${ }^{93}$

Women also became friends while on the job. Lulu Dulin and Della Brown, for example, became close friends while working at Liddle \& Carter; Della even moved in with Lulu's family for a few years. ${ }^{94}$ Garment factories like Liddle \& Carter and WelchCook routinely hired large cohorts of women workers - taking on 15,20 , or even 50 women at a time. Beginning a new job together may have allowed workers to get to know each other and bond more quickly. ${ }^{95}$ Mary Vejda recalled how she became close friends with her Welch-Cook coworkers Albia Stepanek and Bess Kadlec. The three Bohemian American women worked together for years and recalled spending their brief on-the-job rest periods singing and playing a "little organ" and chatting with coworkers while drinking the "coffee, sugar, cream, and canned milk" "we all pitched in 10 cents a week for." After hours, Mary, Bess, and Albia went picnicking and dancing and staged plays and musical events. These close friendships helped make Vejda's eight years as a garment worker more tolerable and her time as a wage earner among the most memorable in her life. ${ }^{96}$ Such "social variables" overlapped with and reinforced identity categories like gender, class, ethnicity, and race that have long been recognized

93. "1898 City Directory Sample and Database”; Federal Census (1900).

94. Cedar Rapids City Directories (1898-1901); Federal Census (1900).

95. “Help Wanted-Female," Gazette, 10/1/1908, 8/29/1912, 8/9/1919; “Help Wanted," Republican, 8/20/1912. For a rarer example of mass hiring at American Cereal, see "Wanted," Gazette, 9/19/1902.

96. "Hemmer Autobiographies"; “Welch-Cook Force Celebrates," Gazette, 7/17/ 1909. Albia was the younger sister of Lizzie Stepanek, a wrapper at American Cereal who became a labor activist. Federal Census (1900, 1910); "Mill Workers New Drill Team," Gazette, 8/19/1904. 
as formative in the development of worker consciousness and collective action. ${ }^{97}$

Personal ties and a largely shared ethnic background created fundamental connections, but it was the existing Liddle \& Carter workers' collective sense of themselves as white women that most significantly informed their labor activism in September 1897. As a press report succinctly explained, "The whites would leave were the colored girls allowed to sit down to a machine." 98 Their only grievance was that they did not want black women working at the factory. ${ }^{99}$ The white workers initiated their collective action to maintain what they perceived to be "their" jobs - a different and better class of work they believed should be reserved for white women. As many other white working-class women in many other places had done, the Liddle \& Carter operatives "deployed collective action to exclude women of color." 100 When it came to the hiring of the black women, it was the Liddle \& Carter operatives' "whiteness" that triggered their instant solidarity. White racial identity subsumed any sense of personal connections to the seven black women or any class or gender solidarity with them.

"Old stock" native-born Americans at the time might not have thought of the predominantly Bohemian women as truly or

97. Katrina Srigley, “ 'In Case You Hadn't Noticed!': Race, Ethnicity, and Women's Wage-Earning in a Depression-Era City," Labour/Le Travail 55 (2005), 74-75.

98. "CRB," Bystander, 9/10/1897. Although this Bystander account said that only "some of the white employes objected to the hiring of the black women," other versions claimed that "the white women and girls rose up unanimously." "Threatened to Strike," Gazette, 9/2/1897. In the end the white women collectively walked off the job to protest the hiring of the black women.

99. Some coverage said the refusal to hire the women had to do with the inexperience of the seven black women. "Color Line," Gazette, 9/4/1897; "Not on Color Line," Gazette, 9/7/1897. However, this seems to have been an excuse rather than an explanation. To begin with, in its August 1897 notices, Liddle \& Carter had not advertised for "experienced" seamstresses, as it did on some other occasions (see previously cited help wanted ads and "Hemmer Autobiographies"). Further, manager Clark had clearly found the applicants qualified enough to hire. Additionally, most of the white women had begun their careers as garment workers with little to no experience. At one point Raspberry publicly stated that if experience was the issue, he could "get experienced colored girls here within twenty-four hours to take their [the white workers'] places." "Color Line," Gazette, 9/4/1897.

100. Dana Frank, “White Working-Class Women and the Race Question," International Labor and Working-Class History 54 (1998), 91. 
fully white, but the operatives at Liddle \& Carter clearly thought of themselves as "inhabit[ing] a racial position above African Americans." Prejudice against black women was particularly entrenched in garment and textile factories. Throughout most of the nineteenth and twentieth centuries, white working-class women's "labor agitation" in garment, textile, and other factories was most often initiated to exclude or "rid their workplace of black employees." Not only did race and white privilege shape women's employment patterns, they also informed consciousness and collective action. White women's activism was initiated to preserve "better" jobs for themselves. In this way, explains Eric Arnesen, "white workers actively participated in the construction ... of their own 'whiteness.' . . . Racism and racial identity were not imposed from without but were created from within on the basis of workers' own experiences and the advantages they afforded." White women gained real economic advantages from maintaining the color line in women's employment as well as what W. E. B. Du Bois described as a "public and psychological wage." $101 \mathrm{Du}$ Bois and other black commentators observed that white workingclass women consciously asserted a white racial identity in order to exclude black women from certain categories of employment and to assert their own respectability.

While cultural perceptions were shifting during this period as more white women entered the workforce, white working-class women still often had to assert and defend their reputations as respectable ladies - to distance themselves from perceptions that they were sexually available or less-than-moral because they spent significant time outside of the "feminine" domains of home and family. ${ }^{102}$ White working-class women could not always distance

101. Frank, “White Working-Class Women and the Race Question," 82, 93; Terborg-Penn, "Survival Strategies," 148; Jones, Labor of Love, Labor of Sorrow, 148; Lois Rita Helmbold and Ann Schofield, "Women's Labor History, 17901945," Reviews in American History 17 (1989), 513; Arnesen, "Up from Exclusion," 163; W. E. B. Du Bois, Black Reconstruction in America, 1860-1880 (1935; reprint, New York, 1998), 700-701. See also Frederickson, "I Know Which Side I'm On," 159; and Hunter, To 'Joy My Freedom, 114-20.

102. Wood, Freedom of the Streets, throughout but esp. 117 and 256. For more on white working-class women confronting perceptions that they were not ladies, see Enstad, Ladies of Labor, Girls of Adventure, esp. 14; and Helmbold and Schofield, "Women's Labor History." 
themselves from women of color in neighborhoods or schools, but workplace segregation was seen as providing protection and distance from the "questionable" reputations of women of color. ${ }^{103}$

White working-class women certainly faced struggles to define themselves and to have others think of them as ladies as well as laborers, but black women had a heightened understanding of what it meant to not be viewed and respected as ladies. African American women of all classes had long faced white cultural stereotypes that they were lacking in "morality, delicacy, refinement and other attributes of white femininity" and were sexually promiscuous and available. They were accorded little protection against sexual harassment and unladylike treatment, and "were portrayed as not needing it" in the first place. In the latter decades of the nineteenth century, black women actively worked to combat such perceptions and to claim identities as ladies. One of the primary aims of the National Association of Colored Women's Clubs, founded in 1896, was to "attack ... the derogatory images and negative stereotypes of Black women's sexuality." Famous women like Ida B. Wells, Mary Church Terrell, and Fannie Barrier Williams, as well as lesser-known figures like Emma Oliphant, self-consciously asserted their identity as ladies. ${ }^{104}$

For African American women, asserting "ladyhood" was also an important way to protest racial discrimination. Black women brought many lawsuits during this period-including at least one notable one in Iowa - that challenged their exclusion from "ladies" accommodations on trains, streetcars, and steamboats because they were not perceived by whites to be ladies; instead, they were categorized only as black and were expected to travel in the inferior accommodations intended for men of all races and

\footnotetext{
103. As Karen Brodkin observes, it was "the jobs of white working-class women [that] separated them from men and women of color. Segregation was the most common way of signaling and ostensibly protecting the respectability and femininity of white women wage earners." Brodkin, "Race and Gender in the Construction of Class," 474. See also Frank, "White Working-Class Women and the Race Question," 87.

104. Darlene Clark Hine and Kathleen Thompson, A Shining Thread of Hope: The History of Black Women in America (New York, 1999), 215; idem, "Rape and the Inner Lives of Black Women in the Middle West," Signs 14 (1989), 912-20; Brodkin, "Race and Gender in the Construction of Class," 475; Welke, Recasting American Liberty, 296-97.
} 
classes. In response, black women sued transportation companies. "Without exception," historian Barbara Welke explains, "black women ... stressed in their complaints that they were ladies; many did not even mention that they were black." The cases, as one of these late nineteenth-century petitions phrased it, were about defining "who is a lady." 105

At Liddle \& Carter, the black women's entire challenge to the color line was based on the claim that these jobs were specifically open to women and, as women, they, too, should be able to work at the factory. Of course, Oliphant and the other black women knew that such factories only hired whites, but in applying for the jobs the women were emphasizing their gender status. For that matter, manager Clark had initially hired the seven applicants because they were female. Oliphant and the other women were asserting that gender should supplant race and that black women were entitled to the same job opportunities as white women.

The black women seem to have anticipated that their gendered claims and assertions of ladyhood might be questioned. Although Oliphant was well known in Cedar Rapids as "the belle of her race," and although she and the other women were clearly not afraid to take public action themselves, they allowed William Raspberry and a committee of five black men to speak for them publicly and "arbitrate the matter." Doing so asserted to the wider white community that the black women were ladies - women protected and "looked after" by "their" men. In fact, the Gazette specifically noted that William Raspberry was "looking after the interests" of the "colored working girls." 106 This was a signal to white residents of Cedar Rapids that the black protesters were respectable ladies - a point that clearly had to be asserted to many whites at the time, including manager Clark.

DURING THE CONFRONTATION on September 2, Clark failed to see or treat the black women as ladies. Instead, he "shoved" and "abused" them. As he "became very angry and tried to

105. Welke, Recasting American Liberty, 296. For the Iowa case, Coger v. North West Union Packet Co. (1873), see Welke, Recasting American Liberty, 293-84, 292-93; and Schwalm, Emancipation's Diaspora, 204-6.

106. “Color Line," Gazette, 9/4/1897; “Not the Foreman,” Gazette, 9/20/1897. 
thrust them from the building, ... he shoved Miss Emma Oliphant against the door, almost breaking her arm." 107 In response, Oliphant-like many other late nineteenth-century black women - filed two lawsuits. With these suits, she was insisting that the seven African American protesters were both laborers and ladies.

The first suit sought remuneration from Liddle \& Carter for Oliphant's efforts in securing the jobs in the first place. With this claim, Oliphant was emphasizing that the black women were workers whose time and labor were valuable-indeed, just as valuable as that of the white women already working at the factory. Oliphant asked for $\$ 5$, the equivalent of a very good week's wages for a female factory worker at the time. ${ }^{108}$ By seeking monetary compensation, Oliphant was asserting that the time invested in applying and reporting for work ought to be compensated - and a judge agreed. By the end of September, Oliphant won this suit, and Liddle \& Carter was ordered to pay "the sum of $\$ 5.00$ for services rendered." 109 That verdict and compensation affirmed the black women's identity as laborers.

That victory must have been satisfying, but the women probably would have preferred being permanently hired at Liddle \& Carter. Within a week of the September 2 confrontation, manager Clark acceded to the white workers' demand to maintain the color line, and their strike came to an end. Although the black women had initially resolved that they would continue to try to secure jobs at the factory, by the end of September William Raspberry "advised the colored girls to make no further application for work, believing that it is for the best and because of having been advised by his attorney that it is the best course to pursue." At that point, reported the Gazette, "much, it is said, will hinge on the outcome of the damage suit." 110

The victory in the first suit recognized the black women's identity as laborers, but only a victory in the second suit would

107. Bystander, 9/10/1897. See also Bystander, 9/17/1897; "News in Iowa," Marion Sentinel, 9/30/1897.

108. The figure might also have represented the sum of a day's factory wage for each of the seven protesting women.

109. “CRB," Bystander, 10/8/1897; “News in Iowa," Marion Sentinel, 9/30/1897.

110. "Not the Foreman," Gazette, 9/20/1897; "Not on Color Line," Gazette, 9/7/ 1897. 
publicly acknowledge their ladyhood. That suit charged manager Clark with "willfully and maliciously assaulting" Emma Oliphant on the morning of September 2 as he "pushed her out of the door and otherwise handled her roughly" by either almost breaking or at the very least "bruising her arm and greatly injuring her feelings." 111 With this suit, Oliphant deliberately proclaimed that she was a respectable lady entitled to considerate, respectful, gentlemanly treatment. Oliphant's suit was clearly "intertwined with claims about rights based on class, gender, and respectability." 112 The fact that Oliphant sought much greater damages $-\$ 99$ by most accounts but upwards of $\$ 3,000$ in others - in the second suit is telling. The principle of the whole Liddle \& Carter matter - that the black women were entitled to the same job opportunities and respectful treatment as white women - may have been the most important.

Then, after a year of struggle and legal postponements, and just as the case was about to be heard in Linn County District Court, Emma Oliphant suddenly, in mid-October 1898, dropped her second suit against Liddle \& Carter. As the Gazette reported, "the case of Oliphant vs. Liddle \& Carter was dismissed by the plaintiff without prejudice." 113 Her decision may have been connected to Liddle \& Carter's involvement in a series of other legal and financial battles over owner J. B. Carter's questionable personal and corporate financial practices. By early October 1898, the company was declared "wholly insolvent." "114 Oliphant must have seen little prospect of recovering the damages and, although

111. "'Color Line,'” Gazette, 9/4/1897.

112. Welke, Recasting American Liberty, 302.

113. "The County Seat," Gazette, 10/13/1898. Oliphant's second suit was first set to be heard in Linn County District Court in November 1897 and repeatedly appeared in court docket and jury selection notices in local newspapers throughout 1898. "CRB," Bystander, 10/8/ 1897; "The District Court," Marion Register, 12/27/1897; "Assignment of Jury Cases . . . Linn Co., District Court," Marion Register, 9/26/1898; "The County Seat," Gazette, 10/3/1898. No further records of the case beyond those reported in local newspapers survive. The registers and records of civil cases from the Linn County District Court were destroyed in the Cedar Rapids flood of 2008.

114. “Affairs of J. B. Carter Attract Much Attention," Gazette, 10/31/1898; “Judge Giberson Makes a Finding in the J. Burdine Carter Case," Gazette, 1/10/1899. The company continued under the name Liddle McDaniel Co. and later Clark McDaniel, which operated until 1930. Linn County Timelines, October 1997. 
a ruling in her favor might still have meant a great deal, she decided it was no longer worth pressing the case.

In the end, Oliphant's attempt to publicly affirm her ladyhood did not come to fruition. She was not hired for a factory job; nor was she victorious in the assault and mistreatment case. Perhaps this, too, underscores the power of race over class and gender in this context. At Liddle \& Carter, race was clearly the heart of the matter; as William Raspberry asserted, employment discrimination had "no basis except the color line." 115 Frustrated with and all too aware of the de facto and de jure discrimination of the 1890s, Oliphant and Raspberry were among the many African Americans who pushed back against the color line-and who came up against just how entrenched it was.

Less than two weeks after the dismissal of the second suit, Oliphant must have watched with more than a little consternation as another group of female workers at another Cedar Rapids factory succeeded in their labor protest. In October 1898 the labor activism and identity of the 150 wrappers who went on strike at American Cereal were informed by the women's personal connections and shared sense of themselves as laborers, ladies, and white Americans of European ethnicity. The wrappers asserted that management had disrespected them as workers by failing to provide "living wages"; as ladies and as Bohemians by declaring that "Bohemians were easy"; and as whites by trying to "make slaves of us." 116 Throughout their strike and labor activism, the wrappers consciously affirmed their "notions of their respectability" and "articulated their identities as women [and] workers," as foreigners and as whites. ${ }^{117}$ Like the Liddle \& Carter garment workers, the American Cereal wrappers embraced and leveraged their collective identity into successful labor activism; within a week of their walkout, the wrappers had won their strike and "secured all that they asked." 118 One can only imagine what Emma Oliphant and other black women in Cedar Rapids might have

115. “Color Line," Gazette, 9/4/1897.

116. "They Take Action," Gazette, 10/27/1898; "Still Out," Gazette, 10/24/1898.

117. Srigley, “In Case You Hadn't Noticed!" 75. See also Enstad, Ladies of Labor, Girls of Adventure, 13.

118. “Girls Have Won Strike," Gazette, 10/28/1898. For a more detailed account of this strike, see Stek, “The 1898 American Cereal Company Strike." 
thought about the wrappers' victory in securing better working conditions for themselves.

EMMA OLIPHANT continued to work for wages for most of the rest of her life. After a brief stint as a live-in domestic, Oliphant went to work for African American business owner O. B. Claire. In the late 1890s Claire opened a lunch stand and confectionary and ice cream shop, which he immediately hired Emma Oliphant to help run. Oliphant worked there until approximately the summer of 1900, when she once again briefly returned to domestic work. ${ }^{119}$ A year later, she married Squire Louis (S. L.) Persons in "a small but pretty wedding" at the Oliphant family home on Tenth Avenue. 120

After marrying, Emma Oliphant Persons appears to have stayed out of the workforce for a few years. She continued to socialize, but the number and variety of her activities dropped off substantially. ${ }^{121}$ Squire and Emma never had any children, and by at least 1910 Emma had re-entered the labor force, this time as a manicurist-a self-employed occupation that allowed her full control over her working life. Her decision to return to work

119. Federal Census (1900); Cedar Rapids City Directory (1901). Claire was also a pioneer of workplace integration in Cedar Rapids. He was the first black member of the Cedar Rapids Police Department. It is not clear whether Claire chose to leave the police department or was forcibly replaced, but by 1899 his position had been given to a white man. Claire then worked as a night janitor at a school and ran the lunch stand business during the day. Bystander, 5/12/1899, 9/22/1899, 10/27/1899, 8/17/1900; Federal Census (1880).

120. “In Matrimonial Bonds," Republican, 11/21/1901; “Iowa Marriage Records, 1901" (accessed via ancestry.com); Federal Census (1900); Cedar Rapids City Directories (1899-1901). Persons's name appears in records as "S. L.," "Squire Louis," "S. Louis," and "S. Lewis" Persons. He settled in Cedar Rapids in the early 1890s after migrating from Tennessee with his wife, Hattie, and younger brother, Benjamin. Squire and Hattie were prominent in the Cedar Rapids black community. Squire worked for many years as a hotel porter, and within just a few years of settling in Cedar Rapids had purchased a home at 712 Ninth Avenue East. Hattie died of consumption in January 1901. Kelli Shipley West, "The Persons' Family," unpublished research paper, Coe College, April 2014; Iowa State Census (1895); Cedar Rapids City Directories (1893-1918); Federal Census (1900, 1910); “CRB," Bystander, 7/23/1897, 10/29/1897; “Obituaries," Gazette, $1 / 16 / 1901$.

121. In the first two decades of the twentieth century, only a handful of notices in the Bystander mentioned Emma Oliphant Persons. "Cedar Rapids News," Bystander, 10/28/1904, 12/2/1904, 7/5/ 1912, 3/3/1905. 
was also likely once again connected to the economic status of her household. The 1915 Iowa census reported that Squire's total yearly earnings working as a "shoe-shiner" and porter at the Allison Hotel amounted to just $\$ 480$. Although she was likely still working as a manicurist, that same census listed no occupation or earnings for Emma. ${ }^{122}$

Within just a year or two of that census, most traces of the working life and activities of Emma Oliphant Persons fade from historical records. She appeared sporadically in city directories from 1917 to 1920 and, although still married, was not listed as part of Squire's household in the 1920 census. Instead, she was listed among the patients living at the Iowa State Hospital in Independence, where she was one of just two black women among some 450 female patients. She died in Independence later that year at the age of 44 . Two days later, her husband and surviving siblings attended her funeral at the Bethel Church in Cedar Rapids. She is buried in Oak Hill Cemetery in Cedar Rapids. ${ }^{123}$

THE STRUGGLES of black women like Emma Oliphant to be treated fairly and equally as ladies and laborers would persist for years to come, in Cedar Rapids and across the nation. In the 1890s black women and men actively worked to improve their own individual circumstances and, as Leslie Schwalm puts it, to force "a renegotiation of the 'place' of African Americans in the North." 124 Black women were particularly important agents in the civil rights struggles of the late nineteenth century, as gender created a space for them to advance claims to rights and opportunities they had been denied because of race. The story of Emma Oliphant and the other working-class women involved in the confrontation over the color line at Liddle \& Carter deserves to be known, as it illuminates a great deal about women's work, labor activism, and racial, gender, and class identity formation in late nineteenth-century Iowa. Oliphant used labor activism and legal suits to advance claims to fair and equal treatment as a lady,

122. Cedar Rapids City Directory (1910); Iowa State Census (1915).

123. Federal Census (1920); “Funeral of Mrs. Emma Persons," Gazette, 10/16/ 1920; "Sites and Structures: Mental Health Institute," Buchanan County Historical Society, http:/ / www.buchanancountyhistory.com/mhi.php.

124. Schwalm, Emancipation's Diaspora, 1. 
a laborer, and an African American living in a society that sought to marginalize all of those identities. She was an ordinary yet extraordinary African American woman who helped to renegotiate the "place" of black working-class women when she challenged the boundaries of racial restriction in women's employment in late nineteenth-century Cedar Rapids. 